\title{
A South African Study Of Influence Of Fairness Of Human Resource Management Practices On Service Quality
}

Lineo Winifred Dzansi, Ph.D., Central University of Technology, South Africa

\begin{abstract}
This paper deals with the problem of poor service delivery in municipalities across South Africa - a problem that seems to elude a lasting solution. It assesses the extent to which perceived fairness in human resource management (HRM) practices affect service quality of selected municipalities in South Africa. Falling on organizational justice theory, it is posited that the HRM practices of municipalities could explain the poor service being delivered by municipalities in South Africa. Quantitative data collected from employees of nine randomly selected municipalities in the Free State Province was used to create indices for employee fairness perceptions of HRM practices as well as service quality as perceived by customers. From regression analysis, the results indicate that: employees perceive HRM practices as unfair; service delivery does not meet citizens' expectations; and, statistically speaking, quality of service delivery is significantly and positively related to perceived fairness in HRM practices namely compensation (distributive); recruitment and Selection (procedural); and promotion (procedural) at the .05 and .01 levels of significance - meaning that fair HRM practices are important for quality service delivery.
\end{abstract}

Keywords: Service Quality; HRM Practices; Service Delivery; Employee Fairness Perception

\section{INTRODUCTION}

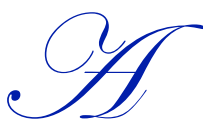

1though the Constitution of the Republic of South Africa (Act 108 of 1996) makes it mandatory for all levels of government, including municipalities, to ensure that service delivered to citizens is of the highest quality (Dzansi \& Dzansi, 2010), judging by current levels of service delivery protests against municipalities across the country, it appears quite to say that the quality of service delivered by municipalities does not meet citizens' expectations.

Service delivery protests across South Africa have led to many problems. For example, dealing with protests consumes time that peace and law-enforcement officers should be devoting to fighting crime. Protests can also be stressful for those dealing with them, and some protests become very violent, resulting in destruction of both private and public property, and even fatalities. Finding effective ways to ensure quality service delivery at the municipality level is therefore a compelling research agenda.

This paper forms part of a wider study into the problem of poor service delivery in municipalities across South Africa - a problem that seems to elude a lasting solution - and assesses the extent to which human resource management (HRM) practices affect quality of service delivered by municipalities. Based on organizational justice theory, it is posited that municipal HRM practices could explain the poor service being delivered by municipalities in South Africa.

\section{LITERATURE REVIEW}

\subsection{The Political Context of HRM In South Africa's Municipalities}

It is useful to consider Senyucel's (2009) observation that effective HRM depends upon the conditions that an organization's setting provides. Thus, the apparent political polarization of municipalities in South Africa might negatively affect the HRM environment in these municipalities. This seemingly deep-rooted polarization creates 
fertile ground for unacceptable HRM practices, such as nepotism based on political affiliation, and the much talked about strategy of 'cadre deployment' (Mashala, 2012), which sees a number of political units being utilized in government departments. The Democratic Alliance (DA) political party in South Africa (2012) concurs that most municipalities have become dumping grounds for cadres that have no understanding or capacity to run local government. The danger of political polarization is therefore real, and is a common feature in municipalities in South Africa - so common, in fact, that HRM practices of municipalities have been subjected to almost daily criticism, and officials are often accused of unsanctioned, self-serving, but mostly politically motivated HRM practices that are divisive, illegitimate, dysfunctional, and counter-productive (Ahmad, 2010). The problem with cadre deployment is that it places loyalty ahead of merit and competence, and it is therefore a serious obstacle to efficient public service (Kanyane, 2012). Areff (2012) states that although competency and ethical standards are critical for effective public service delivery, incompetent and unqualified people, who are unable to deliver services efficiently and effectively, are usually employed in South African municipalities.

These normative assertions are backed by research. For example, a study by Paradza et al. (2010) found political polarization in municipalities and interference in HRM practices in Randfontein Local Municipality and in most municipalities in the Western Cape, Northern Cape, Free State, and KwaZulu-Natal. Similarly, the Department of Cooperative Governance and Traditional Affairs [CoGTA] (2009) found evidence of nepotism, favoritism, erratic appointments and promotions, and posts being filled without having first been advertised.

The draft report of a government-sponsored audit on local government reveals that the practice of nepotism and employing unqualified staff based on political affiliation is in fact a major impediment to service delivery in municipalities (Dzansi \& Dzansi 2010), and needs to be reconsidered. The Democratic Alliance [DA]'s (2012) claims that municipalities throughout South Africa are guilty of appointing officials (particularly senior ones) solely on the basis of political connections, and that municipal managers tend to be underqualified and overpaid - and consequently do not perform, leading to poor service delivery - cannot be dismissed as just a political statement. With already existing human-resource-related challenges of equal opportunities for all citizens, worker motivation, the 'brain drain' to the private sector, and management competency, municipalities cannot afford not to create an environment that is conducive to fair HRM practices. Accordingly, interventions need to be put in place to make a positive impact on the way challenges, such as creating conditions for sustainable service delivery and economic development, are met (Pretorius \& Schurink, 2007).

\subsection{Theoretical Framework - Employee Justice Perceptions and Service Quality}

Even if some or most of these allegations turn out to be unsubstantiated, it is contended that suspicions on their own could impact negatively on service delivery. Employee perceptions of organizational politics can be linked to service delivery in various ways. For example, when it is suspected that a person is employed, promoted, given a pay increase, or given the opportunity to develop on the basis of some party affiliation or certain 'connections' other than merit, this could be perceived by other employees as unfair. This perception could have a negative impact on for example - employees' motivation, commitment, and citizenship behavior, which could eventually affect the quality of service delivered by the municipalities in which those employees work (Dzansi \& Dzansi, 2010). Therefore, astute managerial expediency is required in the way HRM is practiced in municipalities. Politically motivated HRM practices such as cadre deployment cannot be regarded as wise or prudent, since, from an HRM perspective, they can negatively influence municipal service delivery.

From an organizational fairness or justice perspective, it does not help in the attainment of service quality when employees perceive municipal HRM practices as unfair. The reason for this is that if HRM activities are perceived as unfair by service-rendering employees, it may negatively affect the quality of service that employees deliver to communities. Bagraim (2007) supports Adams' (1963) equity theory by explaining that when employees perceive injustice in HRM practices, they change their attitude for the worse, and this affects the service that such employees render to customers on behalf of the organization. Adams' (1963) original equity theory stipulates that when employees make comparisons between efforts and rewards, and perceive there to be unfairness, injustice, or inequity, they will react negatively. It is therefore possible that when municipal employees compare their input/output ratio in terms of HRM practices, and perceive there to be unfairness, it could lower their motivation, organizational commitment, service behavior, and eventually service quality (Morrison, 1996; Van Dyne \& Ang, 
1998; Kreitner \& Kinicki, 2008; Sanders, Dorenbosch \& De Reuver, 2008; Dzansi \& Dzansi, 2010; Ambreen, 2011). It is thus contended that unfair HRM practices will negatively impact quality of service delivery (QSD) in municipalities.

\subsection{Conceptual Framework}

Several studies confirm both a direct and an indirect relationship between HRM practices and quality of service delivery (D'Annunzio-Green, Maxwell \& Watson 2002; Burke \& Cooper 2005; Irfan, Mohsin \& Yousaf 2009; Nakate, 2011). For example, Nakate (2011) demonstrated the relationship between quality of service delivery and justice perceptions of HRM practices. Nakate's study of organizational justice, employee trust, employee commitment, and service quality in the Uganda Revenue Authority (URA) confirms the link between HRM practices and procedures that are perceived to be fair by revenue officers, and the quality of service offered to URA customers. Nakate (2011) further notes that (1) effective HRM practices were essential to service quality, and (2) employees who were satisfied with the organizational justice were more committed to delivering quality service to clients. This implies that fair and just HRM practices enhance service quality. Nakate (2011) also found that an equitable exchange relationship between managers and employees motivated employees to act in accordance with organizational norms that emphasize service quality, and that when fair human resource policies and practices were implemented, they contributed to revenue officers behaving in such a way that service quality was influenced positively. Nakate's study therefore suggests that for municipalities to ensure service quality, they first have to adopt fair and just HRM practices.

Zhang (2009) found that customers' service expectations and service perceptions play a very important role in evaluating the quality of service rendered by service organizations. Thus, simply because it is employees that must render service to communities, their behavior affects how communities perceive the quality of the service rendered by municipalities.

Based on these findings, a conceptual framework has been developed, as shown in Figure 1, to illustrate the hypothesized relationships between employees' perceptions of HRM fairness (PHF) and quality of service delivery (QSD) in municipalities.

Figure 1. The conceptual framework

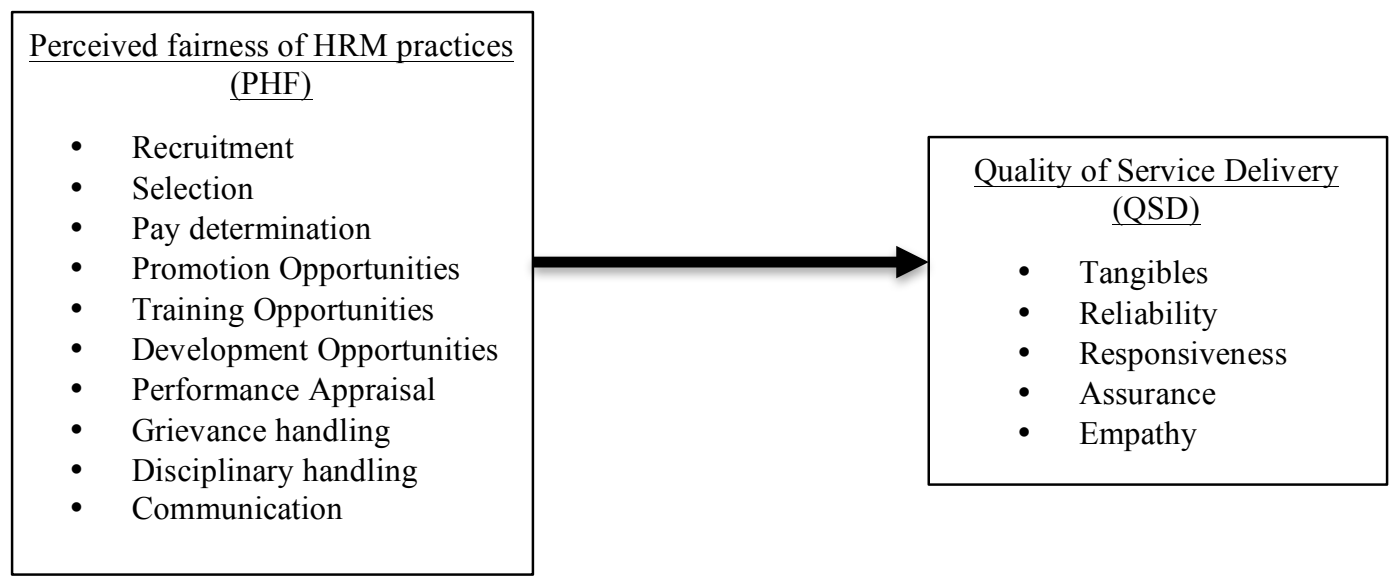

\subsection{Hypothesis}

Based on the above conceptual framework, it is hypothesized that citizens' rating of QSD in municipalities will be positively correlated with PHF. That is: $\mathrm{H}_{\mathrm{o}}=$ Citizens' rating of QSD in municipalities will be positively correlated with PHF; while $\mathrm{H}_{\mathrm{a}}=$ Citizens' rating of QSD in municipalities will not be positively correlated with PHF (where $\mathrm{H}_{\mathrm{o}}$ and $\mathrm{H}_{\mathrm{a}}$ represent the null and alternative hypotheses, respectively). 


\section{METHODOLOGY}

This research follows the positivist epistemology. Positivism is a philosophical approach to research which is founded on the belief that true knowledge can only be created through what can be observed and measured, and tends to rely exclusively on theories that can be directly tested (Bhattacherjee, 2012) or hypotheses that must be proved or disproved (Cohen et al. 2007). Consistent with Bhattacherjee (2012) and Cohen et al.'s (2007) assertions, a conceptual framework (see Figure 1) was developed to show the relationships between variables. Based on this framework, the hypotheses stated above were tested against data (empirical facts) collected from respondents.

\subsection{Design}

Consistent with the positivist paradigm, the research was designed to collect mostly quantitative data, and to use statistical techniques in analyzing the data. It was designed as a cross-sectional study to collect data at a point in time. The study is descriptive in nature, since it only establishes associations between variables.

\subsection{Target Population and Sampling}

The target population consisted of all 20 municipalities in the Free State province of South Africa, and these were divided into four District municipalities, namely: Fezile Dabi, Lejweleputswa, Thabo Mofutsanyana and Xhariep, and the Metropolis of Mangaung. There were two sets of respondents: the first group consisted of municipal employees, while the second was made up of a sample of residents as customers. These respondents were drawn from a sample of nine randomly selected municipalities from the 20 in the Free State province. The primary unit of analysis was each individual local or metropolitan municipality. Throughout the selection of participants, care was taken to determine the correct sample size, and at the same time to ensure the samples represented the true characteristics of the 20 municipalities - two very important characteristics of a good sample (Wagner et al. 2012). Wagner et al. (2012) suggest that the minimum required sample size for a small population is approximately $30 \%$ of the population. However, Ary et al. (2014) claim that the most important characteristic of a good sample is its representivity, not necessarily its size. All of these arguments show that sample size determination is ultimately very much a matter of an 'educated' personal choice. In this study, due to financial and time constraints, the decision was made to limit the number of municipalities to nine randomly selected municipalities out of the total of 20 . For each municipality, 100 questionnaires were randomly distributed to the inhabitants of four randomly selected towns (25 questionnaires per town or village); thus, in total, 900 questionnaires were sent out to citizens (as customers). For employees, the number of questionnaires was restricted to 540, with 60 employees targeted from each municipality. Much effort was invested into ensuring a high response rate. For example, the field workers were allocated only a few respondents. Ultimately, out of the 900 questionnaires sent out to citizens, 821 useful ones were returned, yielding a $91.2 \%$ response rate. Unfortunately, the same high response rate could not be attained as far as municipal employees were concerned. Out of the 540 questionnaires sent out to municipal employees, only 342 completed questionnaires were returned, yielding a $61.9 \%$ response rate.

\subsection{Data Collection}

Structured questionnaires were used to collect data from respondents, some of whom were sufficiently literate and thus completed the questionnaires on their own. Respondents that did not have a sufficient literacy level for solo completion were assisted by trained research assistants to complete their questionnaires.

The questionnaires were based on the Likert-scale format. The questionnaire for customers was developed in three languages: Afrikaans, English, and Sesotho. According to Statistics South Africa [STATSSA] (2011), these three languages are dominant in the Free State province.

Respondent group 1, consisting of municipal employees from various levels of management, as well as nonmanagerial employees who dealt with customers on a daily basis, were required to answer Likert-scale questions on the degree of perceived fairness/justice in HRM practices. Respondent group 2, consisting of 900 residents/customers from local municipalities, were required to rate the quality of service they receive from their local municipalities. 


\subsection{Data Analysis}

Inferential statistics, including Chi square tests, were used to verify the hypothesis. Because analysis of data collected by means of Likert-type questionnaires often attracts attention, it is considered important to explain the procedure followed in the data analysis. Firstly, by using Likert-type questions, critics could argue that an ordinal scale was produced, which would thus limit the analysis to the use of non-parametric statistical techniques. To overcome this, the initial data were transformed into scalar measures as recommended by Vyas and Kumaranayake (2006), Allen and Seaman (2007), and Boone and Boone (2012), to name but a few. Each section in the questionnaire contained a number of questions, which enabled the creation of indices, thus enabling parametric analysis (Vyas \& Kumaranayake 2006; Allen \& Seaman 2007; Boone \& Boone, 2012). Principal component analysis is a statistical technique used to reduce the number of variables in a data set by creating indices (dimension reduction) to represent such data (Vyas \& Kumaranayake, 2006; Boone \& Boone, 2012). A set of, for instance, kvariables (or questionnaire items) is combined into a small number of indices, which are usually arranged in order of importance; this is accomplished by considering their contribution to the total variability of the data (Vyas \& Kumaranayake, 2006). In this study, the most important index, or the first principal component, is considered an adequate representation of a set of questionnaire items. It is also important to point out that on the five-point Likert scale a mean below 3 (the median point) suggests the overall sentiment was negative, and scores above 3 are indicative of a positive sentiment. This was the decision criterion used to reach conclusions about the hypothesis.

\section{RESULTS AND DISCUSSION}

\subsection{Perceived HRM Fairness}

The summaries of HRM practice indices are presented in Table 1. The summaries in Table 1 show that the average responses ranged from 1 (Strongly Disagree) to 5 (Strongly Agree), with means that are generally below the median value of 3. The overall mean of 2.682 is also below the median value of 3 ; thus, it is fair to conclude that the respondents were not pleased with their municipality's HRM practices. In other words, the HRM practices of municipalities lack fairness in the eyes of employees. This finding corroborates that of CoGTA (2009) that political interference in recruitment of the workforce in some municipalities of South Africa has led to unfair HRM practices. Specifically, CoGTA (2009) found salary and benefits disparities between municipal employees of similar ranks. Such disparities are likely to invoke employee displeasure with HRM practices (Ferreira 2012). With municipal employees rating the fairness of HRM so low, it is not surprising that disagreements have characterized South Africa's municipal environment. 
Table 1. Summary statistics for the HRM practices

\begin{tabular}{|c|c|c|c|c|c|}
\hline HRM Practice & $\mathbf{N}$ & Minimum & Maximum & Mean & Std. Deviation \\
\hline \multicolumn{6}{|l|}{ Compensation } \\
\hline Compensation Distribute & 288 & 1.00 & 5.00 & 2.485 & 0.976 \\
\hline Compensation Procedural & 205 & 1.00 & 5.00 & 2.475 & 0.936 \\
\hline Compensation Interactive & 335 & 1.00 & 5.00 & 2.486 & 1.026 \\
\hline \multicolumn{6}{|l|}{ Performance Appraisal } \\
\hline Performance Appraisal Distribute & 325 & 1.00 & 5.00 & 2.455 & 1.126 \\
\hline Performance Appraisal Procedural & 308 & 1.00 & 5.00 & 2.457 & 0.940 \\
\hline Performance Appraisal Interactive & 320 & 1.00 & 5.00 & 2.691 & 0.967 \\
\hline \multicolumn{6}{|l|}{ Disciplinary \& Grievance Handling } \\
\hline Disciplinary / Grievance Handling Distribute & 323 & 1.00 & 5.00 & 2.766 & 1.033 \\
\hline Disciplinary / Grievance Handling Procedural & 301 & 1.00 & 5.00 & 2.910 & 0.892 \\
\hline Disciplinary / Grievance Handling Interactive & 326 & 1.00 & 5.00 & 2.966 & 0.979 \\
\hline \multicolumn{6}{|l|}{ Recruitment and Selection } \\
\hline Recruitment and Selection Distribute & 322 & 1.00 & 5.00 & 2.846 & 1.063 \\
\hline Recruitment and Selection Procedural & 333 & 1.00 & 5.00 & 2.857 & 1.075 \\
\hline Recruitment and Selection Interactive & 339 & 1.00 & 5.00 & 3.025 & 1.102 \\
\hline \multicolumn{6}{|l|}{ Training and Development } \\
\hline Training and Development Distribute & 327 & 1.00 & 5.00 & 2620 & 1.157 \\
\hline Training and Development Procedural & 325 & 1.00 & 5.00 & 2.643 & 1.065 \\
\hline Training and Development Interactive & 330 & 1.00 & 5.00 & 3.017 & 1.028 \\
\hline \multicolumn{6}{|l|}{ Promotion } \\
\hline Promotion Distribute & 334 & 1.00 & 5.00 & 2.349 & 1.109 \\
\hline Promotion Procedural & 323 & 1.00 & 5.00 & 2.447 & 1.091 \\
\hline Promotion Interactive & 334 & 1.00 & 5.00 & 2.514 & 1.037 \\
\hline Overall HRM & 201 & 1.00 & 4.95 & 2.682 & 0.847 \\
\hline
\end{tabular}

\subsection{Quality of Service Delivery}

The summaries for service delivery are presented in Table 2. They show that the average responses to the questions asked under each section ranged from the lowest score of 1 (Strongly Disagree) to 5 (Strongly Agree), with most of the means below 3. Overall, it can be said that the customers were not pleased with service delivery (overall mean is 2.9 , which is below the median of 3). Therefore, the data can be interpreted to mean that, generally, the quality of service delivered by the municipalities surveyed does not meet citizens' expectations. This finding is not at all surprising given negative public sentiments about poor service delivery by South African municipalities. For example, the recent escalation of service delivery protests is an indication that municipalities are not delivering services that meet citizens' expectations (Jain 2010; Karamoko 2011). 
Table 2. Summary statistics for the service delivery

\begin{tabular}{|c|c|c|c|c|c|}
\hline $\begin{array}{l}\text { Service Delivery Item } \\
\end{array}$ & $\mathbf{N}$ & Minimum & Maximum & Mean & Std. Deviation \\
\hline \multicolumn{6}{|l|}{ Tangibles } \\
\hline The municipal has modern equipment & 805 & 1.00 & 5.00 & 3.075 & 1.290 \\
\hline Physical facilities are attractive & 808 & 1.00 & 5.00 & 3.226 & 1.310 \\
\hline Employees are always neat in appearance & 803 & 1.00 & 5.00 & 3.451 & 1.231 \\
\hline Service Materials visually attractive & 798 & 1.00 & 5.00 & 2.996 & 1.233 \\
\hline \multicolumn{6}{|l|}{ Reliability } \\
\hline Interest in solving customer problem & 766 & 1.00 & 5.00 & 2.812 & 1.307 \\
\hline Things are done right at the first time & 792 & 1.00 & 5.00 & 2.400 & 1.229 \\
\hline Service provided as promised & 800 & 1.00 & 5.00 & 2.411 & 1.255 \\
\hline Municipality insists on correct records & 797 & 1.00 & 5.0 & 2.755 & 1.197 \\
\hline \multicolumn{6}{|l|}{ Responsiveness } \\
\hline $\begin{array}{l}\text { Customers informed when services will be } \\
\text { performed }\end{array}$ & 806 & 1.00 & 5.00 & 2.715 & 1.313 \\
\hline Customers are given services on time & 809 & 1.00 & 5.00 & 2.534 & 1.322 \\
\hline $\begin{array}{l}\text { Employees are always willing to help } \\
\text { customers }\end{array}$ & 812 & 1.00 & 5.00 & 2.909 & 1.317 \\
\hline $\begin{array}{l}\text { Employees never too busy to respond to } \\
\text { customers requests }\end{array}$ & 803 & 1.00 & 5.00 & 2.831 & 1.307 \\
\hline \multicolumn{6}{|l|}{ Assurance } \\
\hline $\begin{array}{l}\text { Employees behavior to help customers have } \\
\text { faith in them }\end{array}$ & 789 & 1.00 & 5.00 & 2.827 & 1.276 \\
\hline $\begin{array}{l}\text { Customers always feel safe dealing with } \\
\text { municipality }\end{array}$ & 788 & 1.00 & 5.00 & 2.968 & 1.257 \\
\hline Employees always polite to customers & 775 & 1.00 & 5.00 & 2.981 & 1.295 \\
\hline $\begin{array}{l}\text { Employees always have knowledge to answer } \\
\text { customers }\end{array}$ & 786 & 1.00 & 5.00 & 2.963 & 1.315 \\
\hline \multicolumn{6}{|l|}{ Empathy } \\
\hline $\begin{array}{l}\text { Municipality gives customers individual } \\
\text { attention }\end{array}$ & 804 & 1.00 & 5.00 & 3.041 & 1.256 \\
\hline Operating hours are available to all customers & 793 & 1.00 & 5.00 & 3.192 & 1.253 \\
\hline $\begin{array}{l}\text { Municipality has employees who give } \\
\text { customers personal care }\end{array}$ & 789 & 1.00 & 5.00 & 2.881 & 1.235 \\
\hline $\begin{array}{l}\text { Municipality has the best interest of customers } \\
\text { at heart }\end{array}$ & 799 & 1.00 & 5.00 & 2.717 & 1.295 \\
\hline $\begin{array}{l}\text { Employees understand the specific needs of } \\
\text { different customers }\end{array}$ & 802 & 1.00 & 5.00 & 2.939 & 1.287 \\
\hline Overall Service Delivery & 607 & 1.00 & 5.00 & 2.017 & 0.905 \\
\hline
\end{tabular}

Whilst it may be said that South Africans are too demanding of municipalities in the current democratic dispensation, because it is too early to expect the evils of apartheid to be resolved in a short space of time, 20 years can also be regarded as more than enough time for remedial action. In addition, providing quality service is the mandate of all South African municipalities, just as it is for all publicly funded entities. Therefore, municipalities can never expect to escape criticism when service quality falls short of citizens' expectations. That customers are not pleased with service evokes findings by Abd-El-Salam, Shawky, and El-Nahas (2013), who expressed the opinion that customers are the rightful judges of quality, and also of Denhere at al. (2011), who declared that an organization can only remain relevant in the market when it provides quality services. By delivering services that do not meet citizen's expectations, municipalities are clearly making themselves irrelevant. As Munusamy, Chelliah, and Mun (2010) attest, quality relates to attributes such as relevance to purpose, timely delivery of the service, convenience to users, and responsiveness to users. This means that services being delivered by municipalities may not be relevant to purpose, are not being delivered on time, and/or are not convenient to users. That being the case, there seems to be a need for municipalities to improve in this regard, because it is their responsibility to deliver quality services. Although service quality is 'perceived by customers' it is the responsibility of the service provider to create and deliver services (Abd-El-Salam et al. 2013) that meet customer expectations, and not the other way round. 


\subsection{Effects of HRM Practices (PHF) on Quality of Service Delivery QSD}

Multiple linear regression models were fitted separately to the five variables that measure quality of service delivery, namely, service reliability, tangibles, responsiveness, assurance and empathy. The variables of HRM practice were the predictors (independent variables) in the multiple regression model.

Service reliability was found to depend on the compensation (distributive) of the municipal employees (coefficient $=3.259$, $\mathrm{p}$-value $=0.049$ ). Recruitment and selection (procedural) is also a significant factors affecting service reliability (coefficient $=4.679, \mathrm{p}$-value $=0.035$ ) and so is promotion (procedural) (coefficient $=9.826, \mathrm{p}$ value $=0.039)$. The other HRM practices do not have a significant effect on service reliability.

Responsiveness of municipalities significantly depends on compensation (distributive), (coefficient=2.466, pvalue $=0.047$ ). Recruitment and Selection (procedural) is also a significant factors affecting responsiveness of municipalities (coefficient $=3.752, \mathrm{p}$-value $=0.043$ ) and so is promotion (procedural) (coefficient=7.804, pvalue $=0.049$ ). The other variables of HRM practices have no bearing on responsiveness of municipalities.

Assurance significantly depends on compensation (distributive), (coefficient=-2.946, p-value $=0.046$ ) and not on any other HRM practice.

Empathy significantly depends on compensation (distributive), (coefficient $=-2.834$, $p$-value $=0.050$ ), recruitment and Selection (procedural) (coefficient $=3.632, \mathrm{p}$-value $=0.037$ ) and promotion (procedural) (coefficient $=7.892, \mathrm{p}$ value $=0.046)$. 
Table 3. Multiple regression analysis of QSD on HRM practices

\begin{tabular}{|c|c|c|c|c|c|c|c|}
\hline & \multirow{2}{*}{$\begin{array}{l}\text { Multiple linear } \\
\text { regression }\end{array}$} & \multirow{2}{*}{$\begin{array}{c}\text { Parameter } \\
\text { estimates and p- } \\
\text { values for t-tests }\end{array}$} & \multicolumn{5}{|c|}{ Response Variables: Quality of Service Delivery } \\
\hline & & & Reliability & Tangibles & $\begin{array}{c}\text { Responsi- } \\
\text { veness }\end{array}$ & Assurance & Empathy \\
\hline \multirow{36}{*}{ 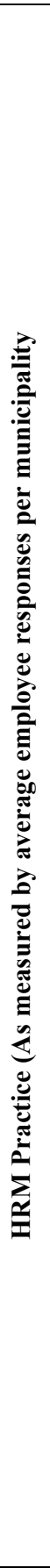 } & \multirow{2}{*}{$\begin{array}{l}\text { Compensation- } \\
\text { Distributive }\end{array}$} & Parameter & 3.529 & -1.367 & 2.466 & 2.946 & 2.834 \\
\hline & & p-value & 0.049 & 0.411 & 0.047 & 0.046 & 0.050 \\
\hline & \multirow{2}{*}{$\begin{array}{l}\text { Compensation- } \\
\text { Procedural }\end{array}$} & Parameter & 4.624 & 0.688 & 3749 & 5.017 & 4.133 \\
\hline & & p-value & 0.199 & 0.857 & 0.248 & 0.157 & 0.183 \\
\hline & \multirow{2}{*}{$\begin{array}{l}\text { Compensation- } \\
\text { Interactional }\end{array}$} & Parameter & -2.655 & 0.299 & -2.537 & -3.520 & -2.283 \\
\hline & & p-value & 0.463 & 0.941 & 0.444 & 0.325 & 0.461 \\
\hline & $\begin{array}{l}\text { Performance- } \\
\text { Appraisal }\end{array}$ & Parameter & -0.060 & 1.818 & 0.483 & 2.946 & -0.504 \\
\hline & \multirow{2}{*}{$\begin{array}{l}\text { Distributive- } \\
\text { Performance }\end{array}$} & p-value & 0.983 & 0.462 & 0.840 & 0.046 & 0.828 \\
\hline & & Parameter & 1.642 & -0.762 & 0.820 & 5.017 & 2.212 \\
\hline & $\begin{array}{l}\text { Appraisal } \\
\text { Procedural }\end{array}$ & p-value & 0.593 & 0.767 & 0.748 & 0.157 & 0.387 \\
\hline & \multirow{2}{*}{$\begin{array}{l}\text { Performance } \\
\text { Appraisal- } \\
\text { Interactional }\end{array}$} & Parameter & -1.584 & -0.967 & -1.284 & -3.520 & -1.694 \\
\hline & & $\mathrm{p}$-value & 0.369 & 0.504 & 0.378 & 0.325 & 0.245 \\
\hline & $\begin{array}{l}\text { Disciplinary and } \\
\text { Grievances }\end{array}$ & Parameter & -0.533 & -1.314 & -0.515 & -0.321 & -0.282 \\
\hline & \multirow{2}{*}{$\begin{array}{l}\text { Distributive } \\
\text { Disciplinary and } \\
\text { Grievances }\end{array}$} & $\mathrm{p}$-value & 0.739 & 0.347 & 0.703 & 0.833 & 0.836 \\
\hline & & Parameter & 1.226 & -0.637 & 0.917 & 0.345 & 1.079 \\
\hline & \multirow{3}{*}{$\begin{array}{l}\text { Procedural } \\
\text { Disciplinary and } \\
\text { Grievances- } \\
\text { Interactive }\end{array}$} & p-value & 0.519 & 0.687 & 0.564 & 0.847 & 0.506 \\
\hline & & Parameter & -1.081 & 2.113 & -0.890 & -0.404 & -1.276 \\
\hline & & p-value & 0.725 & 0.424 & 0.730 & 0.890 & 0.628 \\
\hline & \multirow{2}{*}{$\begin{array}{l}\text { Recruitment and } \\
\text { Selection- } \\
\text { Distributive }\end{array}$} & Parameter & -2.768 & -1.718 & -2.667 & -3.079 & -2.119 \\
\hline & & $\mathrm{p}$-value & 0.164 & $0 . .492$ & 0.143 & 0.165 & 0.258 \\
\hline & \multirow{2}{*}{$\begin{array}{l}\text { Recruitment and } \\
\text { Selection- } \\
\text { Procedural }\end{array}$} & Parameter & 4.679 & 1.744 & 3.752 & 3.240 & 3.632 \\
\hline & & p-value & 0.035 & 0.481 & 0.043 & 0.143 & 0.037 \\
\hline & \multirow{2}{*}{$\begin{array}{l}\text { Recruitment and } \\
\text { Selection } \\
\text { Interactional }\end{array}$} & Parameter & -1.994 & -0.438 & -1.500 & -0.637 & -1.551 \\
\hline & & p-value & 0.348 & 0.873 & 0.430 & 0.780 & 0.446 \\
\hline & \multirow{2}{*}{$\begin{array}{l}\text { Training and } \\
\text { Development } \\
\text { Distributive }\end{array}$} & Parameter & 3.143 & 2.197 & 2.770 & 2.339 & 2.390 \\
\hline & & p-value & 0.096 & 0.176 & 0.075 & 0.206 & 0.152 \\
\hline & \multirow{2}{*}{$\begin{array}{l}\text { Training and } \\
\text { Development } \\
\text { Procedural }\end{array}$} & Parameter & -0.445 & -1.365 & -0.141 & -0.111 & -0.447 \\
\hline & & p-value & 0.781 & 0.360 & 0.750 & 0.946 & 0.761 \\
\hline & \multirow{2}{*}{$\begin{array}{l}\text { Training and } \\
\text { Development } \\
\text { Interactional }\end{array}$} & Parameter & -4.222 & -2.454 & -3.866 & -3.333 & -2.947 \\
\hline & & $\mathrm{p}$-value & 0.165 & 0.346 & 0.124 & 0.273 & 0.273 \\
\hline & \multirow{2}{*}{$\begin{array}{l}\text { Promotion- } \\
\text { Distributive }\end{array}$} & Parameter & -55.071 & -1.955 & -4.120 & -3.916 & -3.756 \\
\hline & & p-value & 0.072 & 0.526 & 0.097 & 0.175 & 0.126 \\
\hline & \multirow{2}{*}{$\begin{array}{l}\text { Promotion- } \\
\text { Procedural }\end{array}$} & Parameter & 9.282 & 3.026 & 7.804 & 7.460 & 7.892 \\
\hline & & p-value & 0.039 & 0.540 & 0.049 & 0.117 & 0.046 \\
\hline & \multirow{2}{*}{$\begin{array}{l}\text { Promotion- } \\
\text { Interaction }\end{array}$} & Parameter & -3.363 & -0.998 & -2.700 & -2.502 & -2.913 \\
\hline & & p-value & 0.110 & 0.671 & 0.145 & 0.248 & 0.124 \\
\hline
\end{tabular}

In general the three HRM practices that significantly impact on quality of service delivery when all HRM practices are considered together, are (i) compensation (distributive), (ii) recruitment and Selection (procedural) and (iii) promotion (procedural). As expected the relationships are positive. None of the HRM practices significantly affect Tangibles as none of the p-values are less than $5 \%(0.05)$. 
The above results confirm the sentiments of researchers/ authors who have argued for fair HRM practices in order for organisations to meet their stated goals. For example, as mention earlier, Brewster et al. (2008) argued for HRM practices such as promotion to be based only on job-related criteria, while HRM procedures should be free from bias and discrimination against employees. Similarly, fairness perception could have a negative impact on quality of service delivered by the municipalities in which those employees work (Dzansi and Dzansi 2010). Bagraim (2007) and Adams (1963) used the equity theory to explain that when employees perceive injustice in HRM practices, they change their attitude for the worse, and this affects the service that such employees render to customers on behalf of the organization. It is therefore not surprising that when the municipal employees compare their input/output ratio in terms of HRM practices they perceive unfairness with customers eventually rating service quality as poor, a finding that is perfectly in line with Adams (1963); Morrison (1996); Van Dyne and Ang (1998); Kreitner and Kinicki (2008); Sanders, Dorenbosch and De Reuver (2008); Dzansi and Dzansi (2010); Ambreen (2011) just to mention a few.

\section{CONCLUSION}

In order to draw inferences from the data, regression analysis was performed and the results helped to accept or reject the hypotheses (see Table 3). On the basis of the regression analysis results, the following conclusions were derived.

As stated earlier, the results of the study show that the null hypothesis $\left(\mathrm{H}_{\mathrm{o}}=\right.$ Citizens' rating of QSD in municipalities will be positively related to employees' PHF) is supported. Therefore, the null hypothesis $\mathrm{H}_{\mathrm{o}}$ is accepted.

It is therefore concluded that in a politically polarized organization like municipalities, where employees are very likely to question every action of the employing organization, one cannot underestimate the influence of employee fairness perceptions of HRM practices on the quality of service delivery.

\section{RECOMMENDATIONS}

\subsection{Recommendations for Practice and Policy}

As Brewster et al. (2008) argued, it makes sense for HRM practices such as promotion to be based only on jobrelated criteria, while HRM procedures should be free from bias and discrimination against employees. As implied by the White Paper on Human Resources Management in the Public Service (South Africa 1997), employees should only be accorded an HRM benefit if the employee deserves it. Grobler et al. (2011) also cautioned that organizations should guard against discriminatory HRM, and advocated that benefits should be provided to all employees in an equitable manner. If perceived to be fair by employees, HRM practices (for example, promotions) can improve employee service delivery. HRM practices can only be seen as fair if employees are treated equally and equitably. Non-compliance with the provisions of the White Paper could promote employee dissatisfaction, with negative implications for municipal service delivery. Current HRM practices such as cadre redeployment (no matter how well defended), nepotism, and discrimination in promotions, etc., are untenable for HRM fairness and QSD. Municipalities are therefore advised to fully consider the detrimental effects of poor HRM practices on service delivery. Because negative justice perception could have a negative impact on employees' motivation, commitment, and citizenship behavior, which could eventually affect the quality of service delivered (Dzansi \& Dzansi 2010), astute managerial expediency is required in the way HRM is practiced in municipalities; and politically motivated HRM practices such as cadre deployment cannot be regarded as wise or prudent, since, from an HRM perspective, they can negatively influence municipal service delivery.

\subsection{Recommendations for Further Research}

The first suggested future research avenue is to conduct a larger-scale study that involves all provinces. It is also recommended that instead of perceptions of service quality, a more objective measure could include document analysis in order to establish planned versus actual service delivery. 


\section{REFERENCES}

Abd-El-Salam, E.M. Shawky, A.Y. and El-Nahas, T. (2013). The impact of corporate image and reputation on service quality, customer satisfaction and customer loyalty: testing the mediating role. Case analysis in an international service company. The Business and Management Review, 3 (2), pp. 177-196.

Adams, J. (1963). Towards an understanding of inequity. Journal of Abnormal Social Psychology, 67(5), pp. $422-436$.

Ahmad, R. (2010). Direct and interactive effects of organizational justice and perceptions of politics on personal and organizational outcomes. Doctoral thesis, International Islamic University, Islamabad.

Allen, E. and Seaman, C.A. (2007). Statistics Roundtable: Likert scales and data analyses. Quality progress. Available at: http://mail.asq.org/quality-progress/2007/07/statistics/likert-scales-and-data-analyses.html (Accessed April 24, 2014).

Ambreen, M. (2011). Impact of implied organizational support on organizational commitment. European Journal of Business and Management 3 (11), pp. 41-45.

Areff, A. (2012). Cadre deployment: loyalty ahead of competence. News 24. Available at www.news24.co (Accessed 12/08/2012).

Ary, D. Jacobs, L.C. Sorensen, C.K. and Walker, D.A. (2014). Introduction to research in education. International Ed. 9th Ed. Belmont, CA: Cengage Learning.

Bagraim, J. (2007). Motivating the South African Workforce. In Werner, A. (ed.) Organisational behaviour, a contemporary South African perspective. 2nd ed. pp. 68-98. Pretoria: Van Schaik.

Bhattacherjee, A. (2012). Social science research: principles, methods, and practices. Florida: University of South Florida, pp. 1143.

Boone, H.N. and Boone, D.A. (2012). Analyzing Likert data. Journal of Extension (50)2. Available at http://www.joe.org/joe/2012april/tt2p.shtml (Accessed August 20, 2012).

Burke, R.J. and Cooper, L.C. (2005). Reinventing human resource management: challenges and new directions. London: Routledge.

Cohen, L. Manion, L. and Morrison, K. (2007). Research methods in education. 6th Ed. London: Routledge.

D'Annunzio-Green, N. Maxwell, G.A., and Watson, S. (2002). Human resource management: international perspectives in hospitality and tourism. London: Thompson.

Democratic Alliance. (2012). Five worst municipalities. Available at www.da.org.za (Accessed April 16, 2012).

Denhere, W. Tafirei, F., Zivanai, O. Lovemore, M. and Chingarande, A. (2011). The quality of service delivery in Zimbabwean urban councils: a case study of Bindura Municipality 2009 to 2011. European Journal of Business and Economics, 5, pp. 68-72.

Dzansi, D. and Dzansi, L. (2010). Understanding the impact of human resource management practices on municipal service delivery in South Africa: an organizational justice approach. African Journal of Business Management, 4 (6), pp. 9951005.

Ferreira, G.M. (2012). State involvement in the conduct of and conditions pertaining to the labour relationship. Administratio Publica: Journal of the Association of South African Schools and Departments of Public Administration and Management 20(2), pp. 132-156.

Fischer, R. (2004). Rewarding employee loyalty: an organizational justice approach. International Journal of Organisational Behaviour, 8(3), pp. 486-503.

Grobler, P. Warnich, S. Carrell, M. Elbert, N. and Hatfield, R. (2011). Human resource management in South Africa. 4th Ed. Johannesburg: Cengage Learning.

Irfan, S.M. Mohsin, M. and Yousaf, I. (2009). Achieving service quality through its valuable human resources: an empirical study of banking sector of Pakistan. World Applied Sciences Journal, 7(10), pp. 1222-1230.

Jain, H. (2010). Community protests in South Africa: trends, analysis and explanations. University of Western Cape. Community Law Centre Local Government Working Paper Series, No. 1.

Kanyane, M. (2012). Cadre deployment: loyalty ahead of competence. HSRC. Available at http.//news24.com (Accessed February 13, 2015).

Karamoko, J. (2011). Community protests in South Africa: trends, analysis and explanations. University of Western Cape. Community Law Centre Local Government Working Paper Series, No. 2.

Kreitner, R. and Kinicki, A. (2008). Organisational behaviour. 8th Ed. New York: McGraw-Hill.

Mashala, P. (2012). Cadre deployment in North West hampers service - Premier. Farmer's Weekly. March 5, 2012.

Morrison, E.W. (1996). Organisational citizenship behaviour as a critical link between HRM practices and service quality. Human Resource Management. 35(4), pp. 493-512.

Munusamy, J. Chelliah, S. and Mun, H.W. (2010). Service quality delivery and its impact on customer satisfaction in the banking sector in Malaysia. International Journal of Innovation, Management and Technology, 1(4), pp. 398-404.

Nakate, M. (2011). Organisational justice, employee trust, employee commitment and service quality in Uganda Revenue Authority. Masters thesis, Makerere University, Kampala.

Paradza, G. Mokwena, I. and Richards, R. (2010). Assessing the role of councilors in service delivery at local government level in South Africa. Research Report 125. Centre for Policy Studies.

Pretorius, D. Schurink, W. (2007). Enhancing service delivery in local government: the case of a district municipality. South 
African Journal of Human Resource Management, 5(3), pp. 19-29.

Sanders, K. Dorenbosch, L. and De Reuver, R. (2008). The impact of individual and shared employee perceptions of HRM on affective commitment considering climate change. Personnel Review, 37(4), pp. 412- 425.

Senyucel, Z. (2009). Managing human resources in the 21 st century. Available at http://www.bookboon.com. (Accessed January 27, 2013)

Republic of South Africa. Department of Cooperative Governance and Traditional Affairs (CoGTA). (2009). Overview Report: National state of Local Governments. Working Documents. Pretoria: Government Printer.

Statistics South Africa [STATSSA]. (2011). Census 2011. Available at http://www.statssa.gov.za/publications/p03014/p030142011.pdf (Accessed July 15, 2013).

Van Dyne, L. and Ang, S. (1998). Organisational citizenship behaviour of contingent workers in Singapore. Academic Management Journal, 41, pp. 692-703.

Vyas, S. and Kumaranayake, L. (2006). Constructing socio-economic status indices: how to use principal components analysis. Health Policy and Planning, 21(6), pp. 459-468.

Wagner, C. Kawulich, B. and Garner Garner, M. (2012). Teaching research methods in the social sciences. Farnham: Ashgate.

Zhang, J. (2009). An investigation into the guests' perceived service quality of the bed-and-breakfast and guest house market industry in the Nelson Mandela Bay Area. Masters thesis, Nelson Mandela Metropolitan University, Port Elizabeth. 